\title{
Strategic architecture as a concept towards explaining the variation in performance of networked era firms
}

\author{
G.M. Mansfield, L.C.H. Fourie* and W.R. Gevers \\ University of Stellenbosch Business School, University of Stellenbosch \\ Stellenbosch 7600, Republic of South Africa \\ glenmans@iafrica.com; Lchf@usb.sun.ac.za; wg@usb.sun.ac.za
}

Received June 2005

\begin{abstract}
In a previous article the authors suggested for networked era firms that latent performance benefits could be found at the confluence of strategy and business models. They argued that the internet and its open standards created an environment making new demands on business that transcend traditional boundaries and call for new patterns of management behaviour.
\end{abstract}

Using these concepts as a starting point, this article develops a construct, strategic architecture, posited as a fundamental, pervasive business phenomenon characterising successful ventures.

Finding strategic intent underpinning strategy and value-creation driving business models, the additional dimensions of dynamic pliancy and harmony are developed. The article concludes with a synopsis of the other literature-based dimensions of the strategic architecture construct which are posited as futurity, customer centricity, market exploitability, economic innovativeness, interjacency, digital spontaneity and scalability, knowledge management, innovative aggressiveness and equivocality.

*To whom all correspondence should be addressed.

\section{Introduction}

As the $21^{\text {st }}$ century dawned it brought to management turbulence and change on a scale not previously imagined. The phenomena of instant gratification, dynamism, choice, and a shifted locus of power that elevated consumer sovereignty to new heights, have impacted on every organisation, commercial or otherwise. Successful performance in this value-driven, connected, evolving landscape demands a review of almost every productive activity. In addition, networks, communications and media have converged with computing to create the challenging business world of now. Email, instant messaging and always-connected cellphones are typical of the systems and devices that dominate business behaviour and consumer lifestyles.

Certain basic philosophies remain unchanged. The centuries-old tenet of a business endures. Independent of its surrounds, driven to serve its customers, a productive enterprise remains a commercial endeavour driven by shareholder wealth, deploying people and resources to generate profits through sustained competitive advantage. The realm of business is also not immune to change. The internet, the world wide web and all the associated economic challenges make new demands on corporate stewards. These, in turn, endeavour to satisfy shareholders by creating new product offerings with lasting effects on people and communities whether they be employees, consumers or ordinary citizens. Effectively meeting these perennial demands in a competitive environment constrains management's battleground to the arena of strategy.

For more than half a century, strategic management has been a prominent field of business and organisational academic research. Its legitimacy is evidenced by the myriads of studies in the literature that comment on the link between effective strategy and related business performance (Venkatraman \& Ramanujam, 1986:801-802). Early studies began by examining the link between management behaviour and organisational performance. In their organisational strategy concept in the late 1970s Miles and Snow (1978), for example postulated that managers develop patterns of strategic behaviour that actively link the internal organisational entrepreneurial, engineering and administrative domains with their perception of the external environment. The researchers classified such patterns into prospectors, defenders, analysers and reactors. A later study into strategy and performance (Snow \& Hrebiniak, 1980:317-336), showed that defenders, prospectors and analysers consistently outperform reactors in competitive environments, but not in an environment that is highly regulated. In a later contingency study Hambrick (1983:687707) found statistically significant differences in the performance (profitability, cash-flow and market-share) of prospectors and defenders as they relate to external characteristics such as the stage in the life-cycle (growth versus mature) and the presence of innovative or noninnovative orientations. Innovation has become an essential contributor to strategy for networked era firms (Hamel, 
2000). In a study conceptualising and measuring strategic orientation Venkatraman (1989:948) added aggressiveness to the innovation dimension, and defined it as the 'posture adopted by a business in its allocation of resources for improving market positions at a relatively faster rate than the competitors in its chosen market.' The items include product innovations and/or market development, improving relative market share and competitive position.

More recent perspectives on strategic management emphasise a greater overlap and interplay between strategy formation and the implementation process (Dobni \& Luffman, 2000:503; Littler, Aisthorpe, Hudson \& Keasey, 2000:411-428; Weir, Kochhar, LeBeau \& Edgeley, 2000). In crafting a strategy it should be forward-looking (as characterised by futurity), and dynamic (Venkatraman, 1989: 948; Hamel \& Prahalad, 1994 \& 1996a). It is no longer appropriate to compete simply on the basis of today's markets and current resources, but rather 'organisations need to be continually pushing back and colonising their own competitive frontier' (Littler, et al., 2000:413). A further requirement for effective strategy formulation is that it should not be confined to the top of the organisational pyramid, but should rather enjoy a much wider constituency of participants in order to maximise the creative and informational input (Hamel \& Prahalad, 1996a; Johnson, Melin \& Whittington, 2003; Simons, 1995:80-87). Effective strategy should be pervasive and needs the broader base of implementation.

The first painful lessons for naïve management and rash investors were learnt from the first quarter of 2000 with the collapse of the 'dot.com' ventures and subsequent loss of billions of investment dollars. After some self-examination, a good measure of humility, and quite some research, concerns began to be raised regarding the way business 'happened' in those times. Eventually the quality and composition of the strategies employed began to be questioned (Finkelstein, 2001; Kanter, 2001; Krantz, 2000). There had to be a way to better understand this networked era and uncover the rules for success that could deliver improved business performance.

Successfully meeting these challenges, demands a different strategic mind-set and flexibility which is no trivial exercise for managers. Even in the light of today's environmental developments there remain certain authorities and managers who cling to the rigid legacy of the past. They are ignorant of the danger that exists, when their ideas are taught or passed on, of their apprentices assuming that yesterday's message is still the gospel for today. This problem illustrates just one intrinsic difficulty facing practitioners and academics as business grapples with how to create sustainable profitability. The attainment and maintenance of sustainable competitive advantage in the networked era is the central theme of this article: what strategies are employed by today's successful ventures - and what are the elements of such strategies.

\section{Strategic intent and value creation}

In the early 1990s, Hamel and Prahalad (1989: 64-65) reported strategic intent to be a driver in certain successful firms. They found strategic intent to be a pervasive ethos, a vision creating and driving ambition almost beyond the firm's abilities. Blind faith, however, has its caveats: excessive reliance on a business model or regarding the traditional process and content of strategy as passé were two often fatal predispositions that existed among internetspawned firms (Kanter, 2001) for several years. Understanding the role and relevance of strategy remains necessary for the effective competitive behaviour of firms in the networked era. 'Strategy is that management behaviour concerned with the firm's creation of sustainable competitive advantage. It reflects the sum of managerial choices and is a blend of deliberate actions, tactical responses and organisational learning' (Mansfield \& Fourie, 2004:35). In the formulation of strategy there is a need to locate the firm as a participant in an industry of similar organisations. Porter (1980) postulated that competitive advantage flowed from the industry position of the firm. However, the relevance of Porter's framework when directed at internet-based firms, whose domain is characterised by turbulence and uncertainty, remains the subject of academic debate (Straub, 2004; Tapscott, 2001:4) which is beyond the scope of this article.

Needing to go beyond an 'industry' explanation of performance gave rise to the resource-based view (RBV) of the firm that builds on Schumpeter's (1934) perspective of value creation which views the firm as a collection of resources and capabilities (Barney, 1991). The RBV posits that effectively deploying a set of complementary, specialised resources and capabilities can create value. Strategic intent underpinned much of the success for traditional firms - its role in the value-creating networked era, however, is more complex.

This conceptual article suggests the convergence between the business purposes of strategic intent and value creation; it uses this as a basis for exploring the differences in performance of networked era firms. '[The economy] has been transformed by digital technology in the "postindustrial" period. Value creation for consumers has shifted from physical goods to an economy that favours service, information and intelligence as the primary sources of value creation’ (Rayport \& Jaworski, 2001:2). Similar sentiments are echoed by other researchers (Eisenmann, 2002; Fjeldstad \& Haanaes, 2001:2; Hamel \& Prahalad, 1996a), authorities such as Hamel (2000) and Thurow (cited by Hax \& Wilde, 2001b:1-4), and popular journals (The Economist, 2000). The internet has also introduced changes in resource markets moving beyond advantages accruing from physical goods to value creation through intangible, knowledge assets. In similar fashion, the business environment is moving towards networks, open markets, mobile labour and information abundance. Generally, resources are becoming increasingly tradable and the advantages accruing from market position and competence inimitability are falling. The resource-based approach to strategy has gradually combined realism with rigour, but remains uneasy about the turbulent environment. Internet-based businesses are dynamic and have learnt to cope and adapt accordingly.

Given the discourse reigning around strategy, unearthing the elusive characteristics of success requires a re-examination 
of fundamental concepts. In the process a framework termed 'strategic architecture' was developed. It was constructed upon historical studies into the strategy and performance of traditional businesses; and then extended further taking the attributes of the networked era into account. One fundamental characteristic evident in today's businesses is agility (Sambamurthy, Bharadwaj \& Grover, 2003; Weill, Subramani \& Broadbent, 2002), extended from the literature, and developed further into the concept of dynamic pliancy.

\section{Dynamic pliancy}

The resource-based view of the firm is one theoretical framework for understanding how competitive advantage is traditionally achieved and sustained. Researchers have extended the RBV to dynamic markets (Teece, Pisano \& Shuen, 1997) with the rationale being that RBV has not adequately explained how and why certain firms have competitive advantage in situations of turbulence. In market conditions such as these, a dynamic capability describes how management 'integrate, build, and reconfigure internal and external competencies to address rapidly changing environments' (Eisenhardt \& Martin, 2000:1106). These authors further maintain that, since manipulation of knowledge resources may impact upon behaviour in such markets, over-dependence on such resources can increase vulnerability. This is especially so, they say, in the prevailing economy where management are challenged to remain competitive.

Eisenhardt and Martin (2000:1107) also suggest the existence of dynamic capabilities within the firm. These are the processes that use resources to match and create market change. They are the organisational and strategic routines by which firms achieve new resource configurations as markets evolve. Effective dynamic capabilities in turbulent markets are simpler than those in less dynamic markets. These routines have few rules restricting managers or indicating priorities (Eisenhardt \& Sull, 2001). The authors find that simplicity ensures focus on broadly important issues without locking them into specific behaviours, or the use of past experience that may be inappropriate given the actions required in a particular situation. Specific strategic and organisational processes include product development, alliancing, and strategic decision-making.

In virtual markets where industry structure may be blurring, dynamic capabilities take the character of simple, experiential processes that rely on quickly created new knowledge and iterative experimental execution to produce adaptive outcomes (Eisenhardt \& Martin, 2000). Learning mechanisms guide their evolution. Dynamic capabilities are necessary, but not sufficient conditions for competitive advantage in these situations. They can be used to enhance existing resource configurations in the pursuit of long-term competitive advantage.

Dynamism as a dimension requires measurement. Dynamism is typified where evidence exists of investment in resources supporting business flexibility. Such resources include managing risk, maintaining multi-skilled staff and the presence of routine practices that enable the business to change direction with minimal disruption (Johnson et al., 2003).

Dynamism without purpose, however, could be misdirected effort. The addition of a marketing context provides the framework for intent. Proponents of dynamic capability should take care not to run through a rough field with binoculars firmly at the eye! In making a case for dynamic capability, however, they should guard against entrenching undue rigidity. One way of counteracting this tendency is to remain firmly market-focused.

Placing dynamic capability within a market context gives this dimension depth, focus and purpose. Dynamic capability with marketing orientation defines the dynamically pliant organisation. Pliancy refers to something easily bent or flexed. It is a readiness to be altered, modified or moulded, to fit conditions. A dynamically pliant organisation is one that is adaptable, re-inventible (Voelpel, Leibold \& Tekie, 2003; Voelpel, Leibold, Tekie \& Von Krogh, 2005) and agile, and can readily take full advantage of market, technology, innovation, or environmental opportunities (Govindarajan \& Gupta, 2001). Dynamic pliancy, then, is the dimension of strategic architecture that reflects such a capability.

Dynamic pliancy in the study is operationalised by the following items:

- Commitment to flexibility confirmed by related investment (Eisenhardt \& Martin, 2000);

- $\quad$ Responsiveness - as in pilot studies or risk evaluation (Teece et al., 1997);

- $\quad$ Flexibility in the deployment of human resources (Eisenhardt \& Sull, 2001);

- Existence of routines and minimal contingency (Eisenhardt \& Sull, 2001); and

- Adaptability with minimal disruption (Eisenhardt \& Martin, 2000).

Strategic intent, business models, futurity, instinctive responsiveness, agility and pliancy, it is contended, are some of the determinants that predicate success. Still lacking, however, is a dimension that effectively reflects the characteristic of successful networked era ventures that convergently integrate and align all their strategies and behaviour into one coherent whole (Chatterjee \& Segars, 2002; Hax \& Wilde, 2001a; Kothandaraman \& Wilson, 2000; Weir et al., 2000), to produce an orchestrated result.

\section{The dimension of harmony}

The information systems (IS) literature emphasises the need for the alignment of information systems goals and strategies with those of the organisation. Alignment is a dominant theme in much IS research (Chatterjee \& Segars, 2002; Norton, 2002; Khandelwal, 2001; Van der Zee \& De Jong, 1999). Such writings have provided a conceptual, 
knowledge foundation for information systems strategy, integrated information systems strategic frameworks (Henderson \& Venkatraman, 1993), competitive advantages from information systems (Venkatraman, 1994), information systems success sustainability factors (Kettinger, Grover, Guha \& Segars, 1994), and buyer-seller strategies in ecommerce (Grover \& Ramanlal, 1999).

Alignment has not been restricted to the IS arena. The development of effective competitive behaviour has lifted management's focus from an operational to a strategic orientation, and created the need for management to develop strategies where resources can be better assimilated into the firm's operations. Effective business strategy implementation demands functional strategies that are well integrated and coordinated. Frenzel (1992:76) proposes that alignment of goals and strategies with the corporate goals and strategies be regarded as a critical success factor, especially for the information-reliant (today's networked era) firm.

As the role of information management becomes more central, leadership, organisation design and management processes also change. To fully realise the competitive advantages created by the strategic use of information, organisations develop appropriate systems-management strategies that fit in with their culture, technology status, and business strategy. For networked era firms such systems serve as a strategic resource. Of similar worth, in integrating all is the vision of the founder, chief executive officer or charismatic leader. This fact is supported by studies of firms, particularly in the early growth phase of their lifecycle (Easton, Brown \& Armitage, 2001; Goldberg \& Sifonis, 1998; MacKay, Reich \& Gemino, 2002; Schwartz, 2003). In one fundamental way, 'alignment' is an input activity; its associated output, however, is harmony.

Harmony, or harmonious, is a 'consistent, orderly, pleasing or agreeable whole, free from dissent or ill-feeling' (Oxford Concise Dictionary, 1988:455). It is the outcome of successful organisational alignment. Vision plays a prominent role in the performance of new e-commerce ventures. Three examples typifying the role and value of vision are Thawte Consulting (founder: Shuttleworth), eBay (founder: Omidyar) (Cohen, 2002) and Amazon (founder: Bezos) (Afuah \& Tucci, 2003:225). The role of the founder is central to creating and maintaining a strong theme or vision that harmoniously unites the organisation and orchestrates all its activities. This phenomenon is evidenced in the successful networked-era businesses. A uniting vision provides the framework for harmony to develop, as is apparent in the examples cited above.

The dimension of harmony has its roots in configuration theory (Miller, 1996). 'A configuration denotes a multidimensional constellation of the strategic and organisational characteristics of a business. Configuration theory postulates that for each set of strategic characteristics there exists an ideal set of organisational characteristics that delivers superior performance' (Van de Ven \& Drazin, 1985). Such configurations are idealistic since they represent 'complex, interdependent and mutually reinforcing organisational characteristics that enable businesses to achieve their strategic goals' (Vorhies \& Morgan, 2003:101). Miller (1996:506) views configuration as 'a variable or quality that can create or destroy competitive advantage'. It is a complex system of interdependencies reflected as 'a quality or property that varies among organisations. It is the degree to which an organisation's elements are orchestrated and connected by a single theme' (Miller, 1996:509).

The dimension of harmony may be operationalised by the following elements, sourced from the literature cited above:

- A primary goal and its attainment is the focus of attention and resources are deployed accordingly;

- $\quad$ Consensus exists on objectives and means;

- Decision-makers share clear priorities;

- $\quad$ Strategy, structure, process and culture, reflected in information, reward or appraisal systems, are shaped by the central vision and complement each other;

- $\quad$ Structure and composition of top management team reflect the focus;

- $\quad$ Hiring, reward and promotion practices are geared to supporting one primary function or talent; and

- Information systems and routines are customised in line with the central theme.

\section{The domain of strategic architecture}

In an earlier paper Mansfield and Fourie (2004) traced the evolution of strategy with the purpose of determining its contribution to their proposed strategic architecture construct. They postulated that the positioning- and resource-based perspectives formed a useful framework. Certain aspects of strategy such as futurity, value creation and strategy-formulation are found to be more effective in coping with complex environments when they are pervasively and fundamentally distributed throughout the firm. Business models, on the other hand, are not opposing; rather they are different. They have, for example, the creation of value as their central purpose (Osterwalder, Pigneur \& Tucci, 2005). To show the value-creating role of business models, it is necessary to locate the business model within the firm, show its relationship with strategy and synthesise the previous concepts into a suitable strategic construct.

\section{Strategic architecture in the literature}

Strategy in the domain of modern businesses must cope with dynamic change and turbulence. At the same time, effective strategy needs to be forward-looking and change-orientated. Organisations must be responsive and adapt to changes within their current operating environments. The better they can predict such changes, the better they can identify and exploit future opportunities. 
The phrase 'strategic architecture' has been used by other authors - but in a different context. Hamel and Prahalad (1990) posit a strategic management framework in which organisations pursue future competitive success through the re-invention of their markets and the deployment of core competencies. The formulation process through which an organisation translates its current core competencies into future competitive success, these authors termed 'strategic architecture' (Hamel \& Prahalad, 1996b:117). Their concept is described as an 'information road map' of the organisation's progress towards its anticipated competitive ambitions, which may not be achieved for several years to come. Hamel and Prahalad (1996b:121) see strategic architecture as 'a broad opportunity approach plan. [It is] ... what we must do today, in terms of competence acquisition, to prepare ourselves to capture a significant share of the future revenues in an emerging opportunity arena.' Their 'road map' not only emphasises the organisation's destination, but also informs about the route necessary to achieve it.

Hamel and Prahalad's method for formulating strategy content presents certain difficulties. Concepts which work well at a corporate level and generically between industries, by their own admission, may be difficult to translate into actual resource allocations in specific organisations (Hamel \& Prahalad, 1996b:223). Management must be able to encapsulate and institutionalise information about core competencies and future competitive ambitions in a tangible way if these are to be managed effectively (Hamel, 2000). To form the basis of a shared dialogue about strategy and to improve strategic fit, strategic architecture must be communicated throughout the organisation.

Commenting on the Hamel and Prahalad concept, which requires 'developing mechanisms for organisational learning, innovation and experimentation, constructive contention, empowerment, optimised value potential, corporate sustainability, and strategic re-framing', Kiernan (1993:7) finds a dichotomy in whether the focus of strategy should be on industry dynamics and competitive structure, or on emerging customer and market needs. He perceives this as artificial and maintains that both factors are important together, but not sufficient for strategic success. Too much of an external focus runs the risk of 'putting the strategic cart before the horse.' He defines internal strategic drivers as the components of strategic architecture, and strategic architecture as "that invisible intellectual, philosophical, and even normative "DNA" which programs and lends coherence to virtually all important business decisions, whether they be strategic or operational' (Kiernan, 1993:7; also compare the concept of the organisational 'meme' as described by Voelpel, Leibold \& Streb, 2005). Kiernan defines strategic architecture as 'a series of overarching corporate priorities and values that form the enabling platform upon which specific strategies can then be built.' The strategic architecture construct posited in this article may have the same label, but it is constructed along different lines - yet, with a similar purpose.

\section{The construct of strategic architecture}

The concept of architecture has common usage in information technology (Morris \& Ferguson, 1993). It has its roots in the field of classical architecture where, from a brief, the structural architect gleans what the client has in mind, and then develops drawings which fundamentally depict the owner's requirements. Detailed plans follow, contractors are appointed and building commences. The architecture is the most fundamental, as in 'basic', or 'foundational', aspect of the building.

'Strategic architecture' in the context of this article, is a complex construct derived to measure the competitive behaviour of a firm, either a pure online or hybrid, participating in the networked era. It is a fundamental philosophy, or orientation, which reflects the attitude and behaviour of management in their quest for sustainable competitive advantage for their businesses.

Strategic architecture does not profess to account for all differences in enterprise performance. There may be other, extraneous, often serendipitous, factors predicating the success of a specific venture. First-mover benefits, for example, have been to the advantage of certain businesses, such as Amazon, which also had enormous financial resources. Many others have been less successful - possibly when their first to market gains became unsustainable possibly due to flagging innovation strategies. Straub (2004:415) maintains that since internet time 'cycles so rapidly, first-mover advantage can only lead to a competitive edge if the builder is already developing the next technological innovation'. The key to effective performance, this article suggests, is dependant on 'deeper' factors which are more under the direct control of management. For this reason the locus of strategic architecture is at the most foundational level in an organisation. The conceptual relationships are shown in Figure 1.

The diagram shows this study's conceptual origin of strategic architecture. Business models give rise to the concept of value; strategy provides the strategic intent. Harmony, knowledge management and dynamic pliancy provide the other bases.

Strategic architecture for a firm competing in the networked era, is a philosophy of strategic intent and value creation necessary for a firm in striving to meet the practical and expressive requirements of its constituents. It is the creative design behind a value proposition and the total basis for a reasoned judgement of a business's performance. It is the fundamental, intellectual, philosophical thread evident at all levels of a business, directing, aligning and delivering coherence in all important business decisions guiding corporate priorities and values, forming an enabling platform for business strategies. 


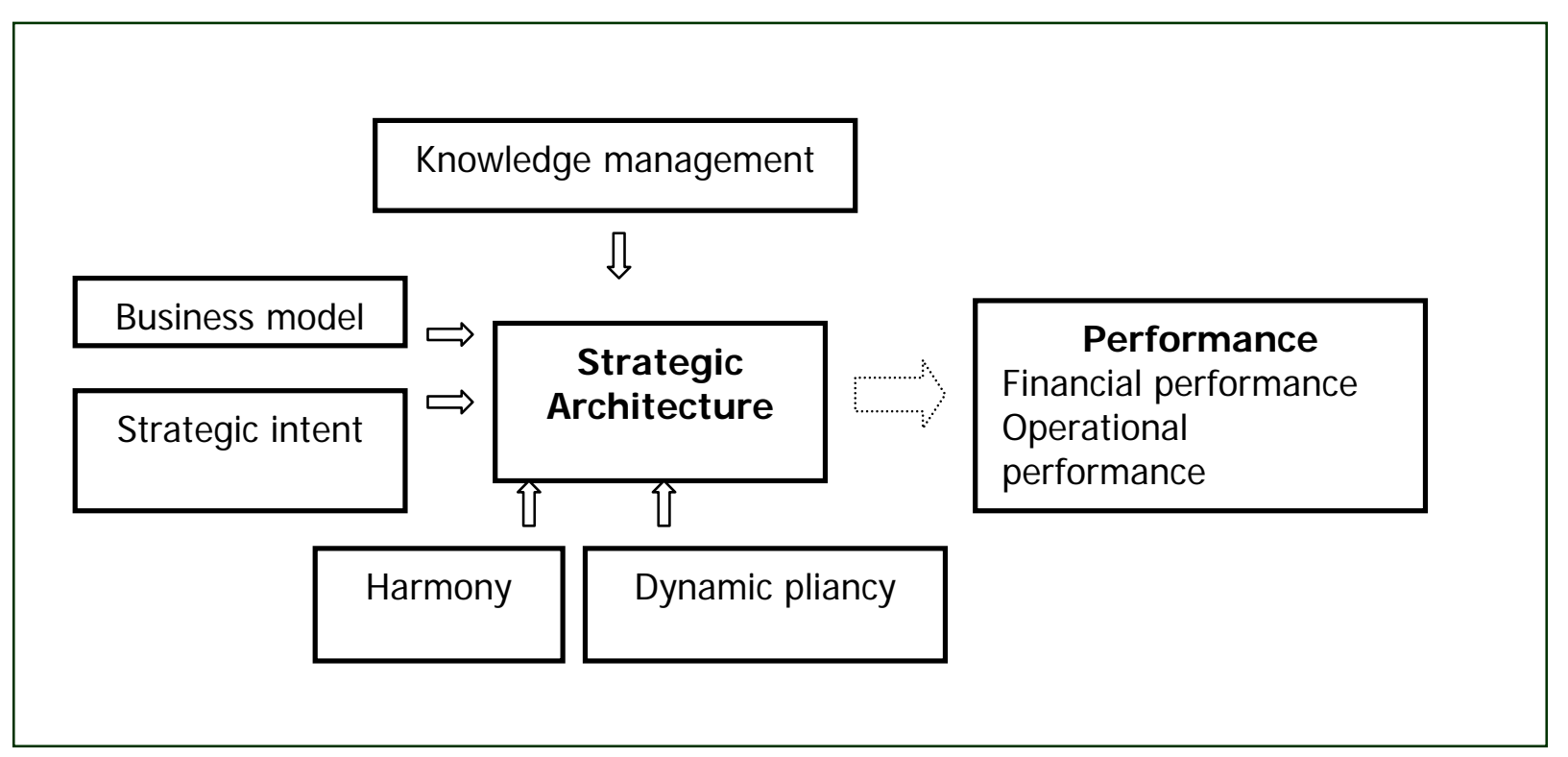

Figure 1: Strategic architecture and its relationship to business performance

There is a conceptual difference between strategic architecture, as propounded in this study, and the 'normal' strategy of a business. The difference is hierarchical. The characteristics of value creation and associated strategic management behaviour are not simply an appendage to an existing strategy set. If this were the case, which functional division, department or manager would, for example, take responsibility for the customer proposition, value-creation, harmony, or innovation? These basic propositions cut across functions. They exist in different forms in different areas of the enterprise. Strategic architecture, as in the construction industry, is the most fundamental of the building blocks of a business. As a building plan has relevance at a higher hierarchical level than its architectural foundation, so business strategy applies at a higher level than strategic architecture. This requirement has become more relevant recently for those businesses adapting to the demands of the networked era. Similar in pervasiveness to organisational culture, strategic architecture exists as the foundation for all strategic management. The connotation of an underpinning structure or framework conveys an appropriate understanding to the meaning as used in the definition. The concept of strategic architecture is rooted, inter alia, in strategy and business models; elements of both these disciplines contribute most to its components.

The differences between strategic architecture as posited in this article, and the concept encountered in the literature, which have been mentioned before, are summarised in Table 1.

Literature on corporate strategy focuses on factors external to the firm such as industry structure and dynamics and resources. Prahalad and Hamel (1996b) use the term strategic architecture in a different but complementary way to refer to 'meta-strategies', which guide the selection and pursuit of a few core competencies.

\section{The dimensions of strategic architecture}

In a recent study into the performance of networked era ventures several dimensions based on an extensive literature study and considered to suitably describe the construct of strategic architecture were eventually identified. The evolution of the strategic architecture construct is based on work published before (Mansfield \& Fourie, 2004), and on the preceding discussion. The origin, content and structure of each dimension is now further elucidated.

\section{Futurity}

Futurity is the existence of a desire by management to achieve a specific future for the business. Encapsulating the purpose of strategic intent, this dimension can be measured by the presence of a clear time horizon, the balance between short-and long-term perspectives, the existence of management objectives, and the firm's overall strategic alignment. This dimension has its origins in strategy and is evident in the criteria for resource allocation. It includes the view of management of how the business should look in three to five years (Alt \& Zimmerman, 2001; Andrews, 1980; Chaffey, 2002; D'Aveni, 1998; Thompson \& Strickland, 2001; Venkatraman, 1989). There should be a sense of purpose with goals formulated by management that guide and align all behaviour, and are reflected throughout the business (Andrews, 1980; Ansoff, 1968). Management are required to demonstrate a commitment to strategic thinking and realise it as an important contributor to their performance. A current strategic plan may serve as a good indicator of attitude (Whittington, 1993).

The overall purpose of business is shareholder wealth, whether a networked era venture or not. This provides the ultimate mission for the venture (Grulke \& Silber, 2000; Hamel \& Prahalad, 1989, 1996b; Thompson \& Strickland, 2001; Venkatraman, 1989). 
Table 1: Conceptual differences in the strategic architecture concept

\begin{tabular}{|c|c|c|}
\hline & $\begin{array}{c}\text { Hamel and Prahalad } \\
\text { (1996b) }\end{array}$ & This study \\
\hline Concept & Process & $\begin{array}{l}\text { Philosophy as in a } \\
\text { motivating concept - } \\
\text { a viewpoint and } \\
\text { system of values }\end{array}$ \\
\hline Origin & $\begin{array}{l}\text { Possibly the result of } \\
\text { semantic conjecture }\end{array}$ & $\begin{array}{l}\text { Grounded in } \\
\text { literature as per the } \\
\text { earlier discussion. }\end{array}$ \\
\hline Perspective & $\begin{array}{l}\text { “Opportunity } \\
\text { approach plan” }\end{array}$ & $\begin{array}{l}\text { Strategic intent (from } \\
\text { strategy) and value } \\
\text { creation (from } \\
\text { business models) }\end{array}$ \\
\hline Focus & $\begin{array}{l}\text { Implementation } \\
\text { processes }\end{array}$ & $\begin{array}{l}\text { Formulation and } \\
\text { content }\end{array}$ \\
\hline $\begin{array}{l}\text { Conceptual } \\
\text { basis }\end{array}$ & $\begin{array}{l}\text { Market re-invention } \\
\text { and core } \\
\text { competencies }\end{array}$ & $\begin{array}{l}\text { Strategy, business } \\
\text { models, harmony, } \\
\text { dynamic capability } \\
\text { and knowledge } \\
\text { management }\end{array}$ \\
\hline Purpose & Management guide & $\begin{array}{l}\text { Indicator of business } \\
\text { performance }\end{array}$ \\
\hline Object & All firms & $\begin{array}{l}\text { Firms predominantly } \\
\text { exposed to the } \\
\text { vagaries of the } \\
\text { networked era }\end{array}$ \\
\hline Time horizon & 'Action today' & $\begin{array}{l}\text { Developing a robust } \\
\text { dynamic strategic } \\
\text { capability }\end{array}$ \\
\hline $\begin{array}{l}\text { Research } \\
\text { construct }\end{array}$ & Not available & $\begin{array}{l}\text { Architecture with } 12 \\
\text { dimensions }\end{array}$ \\
\hline Shortcomings & $\begin{array}{l}\text { 'Difficult to } \\
\text { institutionalise' }\end{array}$ & $\begin{array}{l}\text { Theoretical, and as } \\
\text { yet, untested. It } \\
\text { forms the basis for a } \\
\text { future empirical } \\
\text { study }\end{array}$ \\
\hline Conclusion & $\begin{array}{l}\text { Concept has use with } \\
\text { few citations in the } \\
\text { literature (Littler et } \\
\text { al., 2000) }\end{array}$ & $\begin{array}{l}\text { May contribute to } \\
\text { explaining } \\
\text { performance of } \\
\text { networked era firms }\end{array}$ \\
\hline
\end{tabular}

\section{Customer centricity}

Customer centricity means considering the customer central in every business purpose or transaction. It may be defined by attitudes towards customer bonding; customer-facing website and other front-end performances; after-sales service; measuring performance; establishing and maintaining high switching costs, discouraging customers from buying elsewhere; managing the relationship and eventually 'locking in' the customer. Customer bonding goes beyond customer sovereignty. It is about making customers feel special and relates to every aspect of the firm's customer-facing processes, from web site performance, (Palmer, 2002; Smith, Bailey \& Brynjolfsson, 1999), through security (Hax \& Wilde, 2001a) and followup (Evans \& Wurster, 1999) to after-sales service (J P Morgan, 1999).

What gets measured gets done. Customer strategy effectiveness is gauged by the use of metrics which enable management to maximise a venture's customer online experience. Successful customer centricity raises switching costs and enhances conversion rates that together prevent customers from switching allegiances (Amit \& Zott, 2001; Hax \& Wilde, 2001b). Since most business comes from repeat sales to existing customers, an effective relationship strategy is also required (Hax \& Wilde, 2001b). Listening becomes an important sales attribute. Finally, many successful online businesses Many networked era businesses find that lock-in is enhanced when the product interface becomes a resource rather than a sales channel (Chaffey, 2002; Hax \& Wilde, 2001b). Macro-economic positioning of the firm in its
industry

Macro-economic positioning describes how the firm benefits from being positioned in the right industry at the right time. Flourishing through industry benefits has long been the contention of positioning-based view protagonists. Such measures include benefits from Schumperterian rents, market dominance, first-to-market, cost strategy, process and product differentiation, the non-imitability of competencies and the degree to which competencies are visible to competitors.

Positioning, integrating and defending a firm's position include cash- and benefit-flows to the firm by virtue of its positioning at a point in time, in an industry. Certain valuations accrued to the online firms simply by virtue of the fact that they were perceived to be in the right place at the right time to benefit from the technological advantages of the internet and its technologies (Becker \& Knudsen, 2002; Cohen, 2002; Schumpeter, 1934). In some cases it is possible that, if not checked, such momentum may obscure poor management performance - for a time. Some of the early strategy authors viewed market dominance as the main source of competitive advantage (Miles \& Snow, 1978; Porter, 1980). Others believed that being in the 'right business (internet-based) at the right time' has important implications for the value of the business (Arthur, 1996; D'Aveni, 1998; Kim, Nam \& Stimpert, 2001). Some authors view low-cost as a guarantee for survival (Kay, 1993; Porter, 1985). Porter (1985) has written that differentiation has a positive impact on performance. Other resource-based perspectives (Hamel \& Prahalad, 1990) include the inimitability of core competences (Barney, 1991) which, 
given the covert transparency of the internet, becomes a major issue.

\section{Market exploitability}

Market exploitability is the ability of the firm to generate revenues from intimate market examination and exploiting niches. It includes developing an appropriate business model and creating a dependent community, and evolves from thoroughness of analysis, the orientation of the firm and its pricing policies.

The origins of exploitability lie with some authors who suggest that thoroughness of market examination and identifying niches missed by others, combined with online possibilities, impact positively on performance (Chatterjee \& Segars, 2002; Hax \& Wilde, 2001a; Skyrme, 2001). The firm that can identify, orientate itself and exploit such opportunities should be successful. Interestingly, price, long considered one of the four fundamental tenets of marketing, loses its competitive edge in the case of online firms. Research has indicated that it does not necessarily have the same importance as has traditionally been the case (Bakos, 1997; Brynjolfsson \& Smith, 1999; J P Morgan, 1999). Brand orientation remains important (Brynjolfsson \& Smith, 1999; Noble, Sinha \& Kumar, 2002) and should contribute to profitability.

\section{Economic innovativeness}

Simple e-shops are not very different in nature, operation or structure from their offline retail counterparts. Economic innovativeness describes the 'differentness' of an online venture from an offline business performing the same function. This dimension includes the value to the firm of the web and its technologies (Palmer, 2002; Timmers, 2000), degree of net-enhancement (Timmers, 2000), organisational flexibility (Amit \& Zott, 2001; Barnes-Vieyra \& Claycomb, 2001; Chatterjee \& Segars, 2002; Green \& Himelstein, 1999; Hamel, 2000), structural innovation (Hamel, 2000; Hamel \& Prahalad, 1996a), web-based innovation (Timmers, 2000), the degree of management complacency (Hamel \& Prahalad, 1996b) and perpetual functional integration (Porter, 1985; Rappa, 2002; Timmers, 2000) especially regarding the internet technologies.

\section{Interjacency}

The strategic architectural dimension of interjacency is the ability of the firm to leverage value through intervention in the value- or supply-chains. Disintermediation, a specific case of interjacency (Coase, 1937; Cohen, 2002; Madhok, 2002), is the removal of intermediaries such as distributors or brokers that formerly linked a firm to its customers (Chaffey, 2002:532). This dimension includes how the enterprise benefits from shortening its value-chain (Porter, 1985; Tapscott, Ticoll \& Lowy, 2000) and benefits from creating value through its strategic alliances (Hax \& Wilde, 2001b). It goes beyond simple disintermediation.

Several authors also value alliance-formation (Snow \& Raymond, 1992; Tapscott, 2001; Tapscott et al., 2000; Welborn \& Kasten, 2003), which has become synonymous with networked firms. Such alliances include co-opetition (Tapscott et al., 2000; Welborn \& Kasten, 2003) and outsourcing. The key benefit of such associations should be improved effectiveness.

\section{Digital spontaneity and scalability}

This dimension began as the need for finding an aspect of technology related to an effective information technology (IT) strategy. Computer systems characterise networked era firms. It is the responsiveness of these systems, however, that undergirds performance. Digital spontaneity and scalability is the contribution to flexibility, through the instinctiveness with which such systems respond to the demands of a business. These challenges include change management, being proactive in systems implementation, and how the firm profits generally from information and communications technologies. Some items for measuring this dimension include the perceived alignment of IT with business goals, systems availability, dependence on technology, IT research and development benefits, executive attitudes, management information system performance, investment criteria and asset utilisation.

The dimensions of digital spontaneity are sourced in the alignment of information technologies with business strategy (Chatterjee \& Segars, 2002; Henderson \& Venkatraman, 1993; Norton, 2002; Ragu-Nathan, RaguNathan, Tub \& Shi, 2001; Van der Zee \& De Jong, 1999) and include the concomitant allocation of financial and human resources (Chatterjee \& Segars, 2002; Hax \& Wilde, 2001b). The element of instinctiveness (Venkatraman, 1994 \& 2000) also suggest that effective systems availability will create technology dependence (Straub \& Klein, 2001), which may have a direct bearing on business performance. When technology decisions are made, they should be implemented quickly (Afuah \& Tucci, 2001; Chaffey, 2002; Kaplan \& Norton, 2000; Orlikowski \& Iacono, 2001; Wang, 2001).

Research and development remain key elements of digital performance. Winning firms constantly review technology developments to find ways of staying ahead of competitors (Hamel, 2000). Executive attitude towards research and development, and information technology, remain important e-business adoption factors (Iacovou, Benbasat \& Dexter, 1995; MacKay et al., 2002; Poon, 2000; Poon \& Swatman, 1999). The role of information technology executives in the firm's strategic plan endorses alignment.

Management information systems provide the infrastructure for improved decision-making (Chatterjee \& Segars, 2002; Corbitt, 2000). Often such systems inherit past technologies and policies. Winning firms build on the strengths of such systems, making them relevant in the networked era (Kanter, 2001). Witness to this are the many financial institutions today still running business-critical Cobol systems created in the 1960s. Powerful interfaces have turned antique systems into new, highly-valued, knowledgebased assets. 


\section{Knowledge management}

Knowledge management concerns how the firm uses this resource to create value. It reflects how the firm profits from managing knowledge resources for competitive advantage. The evolution of data to knowledge is facilitated by adding value. The knowledge management dimension is operationalised by the presence of formal and centralised processes that facilitate collecting, storing and deploying key knowledge-based material; improving performance by the retention of key skills; inter-organisational communications; a culture of knowledge sharing, and the location of knowledge within the business.

Knowledge as an object (Sveiby, 1997 \& 2001) acknowledges a formal, centralised, retrievable process where key knowledge-based material is collected, stored and deployed. Knowledge also abides in people (Sveiby, 1997 \& 2001) and the loss of such skills impacts on business performance (Nonaka \& Takeuchi, 1995; Polanyi, 1967). To be mobilised, tacit knowledge needs to be shared (Botha \& Fouche, 2002; Skyrme, 2000), requiring effective corporate communications, and healthy staff attitudes to form the basis of a knowledge sharing culture. Such phenomena are evidenced by the loci of in-house solutions to previouslyencountered business problems (Botha \& Fouche, 2002; Skyrme, 2000).

\section{Innovative aggressiveness}

Every networked era firm has innovation as one of its dominant themes. The study sought to move beyond the simplistic existence of innovation policies by evaluating the degree of aggressiveness with which a firm pursues its innovation strategy. The origins of this dimension are based on the work of Venkatraman (1989). Competitive advantage accrues from how much more aggressive a successful firm might be over its more complacent rival. The measures applied included the relative size of the research and development budget (Hamel, 2000; Venkatraman, 1989), management attitudes to innovation (Hamel, 2000; Hamel \& Prahalad, 1996b; Hamel \& Valikangas, 2003), measuring innovation outputs (Chaffey, 2002; Hamel, 2000), institutionalising innovation through performance appraisal and incentive systems (Hamel, 2000).

Innovativeness, the responsibility and duty of every staff member, has a direct bearing on profitability (Gopalakrishnan, 2000; Hamel, 2000).

\section{Equivocality}

The term 'equivocality' has its roots in the word 'equivocal', which means being open to several interpretations. Applied in this instance, it denotes a measure of the quality of management fortitude. Synonymous with 'ambiguity' or 'ambivalence', it relates to the approach of management towards risk. An irresolute or equivocating management may delay or postpone decisions with an element of risk, which in terms of the demands of networked era could prove unwise. This dimension includes the analytical ability of management, risk-taking
(Venkatraman, 1989), dealing with uncertainty (Corbitt, 2000) and the setting of priorities. It includes management's attitude, which may have special relevance for online ventures spawned by offline businesses, towards legacy issues.

The last two dimensions, harmony and dynamic pliancy have been discussed above. The items identified in this section served as the item pool of the study and formed the basis of the strategic architecture construct.

\section{Conclusions}

The linkage between strategy and performance for traditional business undertakings has been well-documented in the literature. The networked era, spawned by the internet and its technologies, has permanently changed the business environment. In order to explore the strategy/performance link for firms, a construct of strategic architecture is suggested. Strategic management literature revealed the value to the strategy arsenal of any enterprise, whether networked era or not, of strategic intent, industry positioning benefits, risk, core competencies and technology. In addition, the need for value as a core proposition was viewed as one of the main contributions from the literature on business models. The strategic architecture construct was completed by examining the characteristics of networked era firms. Strategic architecture, as with its parallels in the construction industry, is posited as a fundamental blueprint for successful performance.

While this article has provided an account of the origins of the strategic architecture construct and its various dimensions, its scope prevents the concomitant itemisation and development of an appropriate measuring instrument suitable to be administered to strategy formulators, or their equivalents. This is the subject of further research by the authors. What has been suggested should be understood as the basis for further refinement, development, and testing of the construct under actual business conditions, and as the starting point for further scholarly debate and exploration of the relationship between strategic architecture and performance.

\section{References}

Afuah, A. \& Tucci, C. L. 2001. Internet business models and strategies: Text and cases. New York: McGrawHill/Irwin.

Afuah, A. \& Tucci, C. L. 2003. Internet business models and strategies: Text and cases. 2nd edition. New York: McGraw-Hill/Irwin.

Alt, R. \& Zimmerman, H.-D. 2001. ,Preface: Introduction to special section - Business Models', Vol. 11, No. 1: Guest editors note) In Schmit, B. F., Alt, R., Zimmerman, H-D. \& Buchet, B. Anniversary edition: EM-Electronic Markets 11(1):1-15.

Amit, R. \& Zott, C. 2001. 'Value creation in e-business', Strategic Management Journal, 22(6/7):493-520. 
Andrews, K. R. 1980. The concept of corporate strategy. Homewood: Richard D Irwin.

Ansoff, H. I. 1968. Corporate strategy: An analytic approach to business policy for growth and expansion. 1st edition. Harmondsworth: Penguin Books.

Arthur, W. B. 1996. 'Increasing return and the two worlds of business’, Harvard Business Review, 74(3):100-109.

Bakos, J. Y. 1997. 'Reducing buyer search costs: Implications for electronic marketplaces', Management Science, 43(12):1676-1692.

Barnes-Vieyra, P. \& Claycomb, C. 2001. 'Business-tobusiness e-commerce: Models and managerial decisions', Business Horizons, 44(3):13-20.

Barney, J. 1991. 'Firm resources and sustained competitive advantage’, Journal of Management, 17(1):99-120.

Becker, M. C. \& Knudsen, T. 2002. 'Schumpeter 1911. Farsighted visions on economic development', American Journal of Economics and Sociology, 61(2):387-403.

Botha, D. F. \& Fouche, B. 2002. 'Knowledge management practices in the South African business sector: Preliminary findings of a longitudinal study', South African Journal of Business Management, 33(3):13-19.

Brynjolfsson, E. \& Smith, M. D. 1999. 'Frictionless commerce? A comparison of internet and conventional retailers', Management Science, 46(4):563-585.

Chaffey, D. 2002. E-Business and E-Commerce management: Strategy, implementation and practice. Harlow: Pearson Education.

Chatterjee, D. \& Segars, A. H. 2002. Transformation of the enterprise through eBusiness: An overview of contemporary practice and trends. A Second Report to the Advanced Practices Council, 34.

Coase, R. 1937. 'The nature of the firm', Economica, 4:386405.

Cohen, A. 2002. The perfect store: Inside eBay. Boston: Little Brown and Company.

Corbitt, B. J. 2000. 'Developing intraorganizational electronic commerce strategy: An ethnographic study', Journal of Information Technology, 15(6):119-130.

D'Aveni, R. A. 1998. 'Waking up to the new era of hypercompetition', The Washington Quarterly, 21(1):183195.

Dobni, C. B. \& Luffman, G. 2000. 'Market orientation and market strategy profiling: an empirical test of environmentbehaviour-action coalignment and its performance implications', Management Decision, 38(8):503-519.
Easton, R., Brown, R. \& Armitage, D. 2001. 'The dynamics of change in the supply chain - Translating supply chain strategies into action'. In Gattorna, J. (Ed.). Strategic supply chain alignment - Best practice in supply chain management. England: Gower.

The Economist, 23 September 2000:6. 'A survey of the new economy.'

Eisenhardt, K. M. \& Martin, J. A. 2000. 'Dynamic capabilities: What are they', Strategic Management Journal, 21:1105-1121.

Eisenhardt, K. M. \& Sull, D. N. 2001. 'Strategy as simple rules’, Harvard Business Review, 79(1):106-116.

Eisenmann, T. R. 2002. Internet business models: Text and cases. New York: McGraw-Hill.

Evans, P. \& Wurster, T. 1999. Blown to bits: How the new economics of information transforms strategy. Boston: Harvard Business School Press.

Finkelstein, S. 2001. 'The myth of managerial superiority in Internet startups: An autopsy’, Organizational Dynamics, 30(2):172-185.

Fjeldstad, O. D. \& Haanaes, K. 2001. 'Strategy tradeoffs in the knowledge and network economy', Business Strategy Review, 12(1):1-10.

Frenzel, C. W. 1992. Management of information technology. Boston: Boyd \& Fraser.

Goldberg, B. \& Sifonis, J. G. 1998. 'Focusing your e commerce vision', American Management Association International, 9:48-51.

Gopalakrishnan, S. 2000. 'Unraveling the links between dimensions of innovation and organisational performance', The Journal of High Technology Management Research, 11(1):137-153.

Govindarajan, V. \& Gupta, A. 2001. 'Strategic innovation: A conceptual road map’, Business Horizons, 44(4):3-12.

Green, H. \& Himelstein, L. 1999. 'Throw out your old business model', Business Week Online, 22 March. [online] URL:

http://www.businesswek.com/1999/99-12/b3621006 htm

Grover, V. \& Ramanlal, P. 1999. 'Six myths of information and markets: Information technology networks, electronic commerce, and the battle for consumer surplus', MIS Quarterly, 12(4):465-495.

Grulke, W. \& Silber, G. 2000. Ten lessons from the future: 21st century impact on business, individuals and investors. Parklands: @One Communications.

Hambrick, D. C. 1983. 'High profit strategies in mature capital goods industries: A contingency approach', Academy of Management Journal, 26(4):687-707. 
Hamel, G. \& Prahalad, C. K. 1989. 'Strategic intent', Harvard Business Review, 67(5): 63-76.

Hamel, G. \& Prahalad, C. K. 1990. 'The core competence of the corporation', Harvard Business Review, 68(5):79-91.

Hamel, G. \& Prahalad, C. K. 1994. Competing for the future. Boston: Harvard Business School Press.

Hamel, G. \& Prahalad, C. K. 1996a. 'Competing in the new economy: Managing out of bounds', Strategic Management Journal, 17(3):237-242.

Hamel, G. \& Prahalad, C. K. 1996b. Competing for the future. Boston: Harvard Business School.

Hamel, G. 2000. Leading the revolution. Boston: Harvard Business School.

Hamel, G. \& Valikangas, L. 2003. 'The quest for resilience', Harvard Business Review, 81(9):52-63.

Hax, A. \& Wilde, D. 2001a. 'The Delta model - Discovering new sources of profitability in a networked economy', European Management Journal, 19(4):379-391.

Hax, A. \& Wilde, D. 2001b. The Delta Project. Discovering new sources of profitability in a networked economy. New York: Palgrave.

Henderson, J. C. \& Venkatraman, N. 1993. 'Strategic alignment: Leveraging information technology for transforming organizations', IBM Systems Journal, 32(1):13.

Iacovou, C. L., Benbasat, I., \& Dexter, A. S. 1995. 'Electronic data interchange and small organizations: Adoption and impact of technology', MIS Quarterly, 19(4):465-485.

J P Morgan. 1999. E-tailing and the five Cs. New York: J P Morgan Publishing.

Johnson, G., Melin, L. \& Whittington, R. 2003. 'Micro strategy and strategizing: Towards an activity-based view', Journal of Management Studies, 40(1):3-22.

Kanter, R. M. 2001. 'The ten deadly mistakes of WannaDots', Harvard Business Review, 79:91-100.

Kaplan, R. S. \& Norton, D. 2000. Creating the strategyfocused organisation. Boston: Harvard Business School Publishing.

Kay, J. 1993. 'The structure of strategy', Business Strategy Review, 4(4):17-37.

Kettinger, W. J., Grover, V., Guha, S., \& Segars, A. H. 1994. 'Strategic information systems revisited: A study in sustainability and performance', MIS Quarterly, 18(1): 3158.
Khandelwal, V. K. 2001. 'An empirical study of misalignment between Australian CEOs and IT managers', Journal of Strategic Information Systems, 10: 15-28.

Kiernan, M. J. 1993. 'The new strategic architecture: Learning to compete in the twenty-first century', Academy of Management Executive, 7(1):7-21.

Kim, E., Nam, D. \& Stimpert, J. L. 2001. 'Testing the applicability of Porter's generic strategies in the digital age: A study of Korean cyber malls'. Paper read at the 21st Annual International Strategic Management Conference, San Francisco, October.

Kothandaraman, P. \& Wilson, D. T. 2000. 'Implementing relationship strategy', Industrial Marketing Management, 29(4):339-349.

Krantz, M. 2000. Dot-coms without plans die. [online] URL: http://www.usatoday.com/money/dotcoms/dot038 htm.

Accessed 4 Dec 2000.

Littler, K., Aisthorpe, P., Hudson, R. \& Keasey, K. 2000. 'A new approach to linking strategy formulation and strategy implementation: An example from the UK banking sector', International Journal of Information Management, 20:411 428.

MacKay, N., Reich, B. \& Gemino, A. 2002. 'Using cases to explain electronic commerce adoption and success in small and medium-sized enterprises'. Paper read at the ASAC 2002 Conference, Winnipeg, Manitoba.

Madhok, A. 2002. 'Reassessing the fundamentals and beyond: Ronald Coase, the transaction cost and resourcebased theories of the firm and the institutional structure of production', Strategic Management Journal, 23(6):535-550.

Mansfield, G. M. \& Fourie, L. C. H. 2004. 'Strategy and business models - strange bedfellows? A case for convergence and its evolution into strategic architecture', South African Journal of Business Management, 35(1):3544.

Miles, R. \& Snow, C. 1978. Organizational strategy, structure, and process. New York: McGraw-Hill.

Miller, D. 1996. 'Configurations revisited', Strategic Management Journal, 17(7): 505-512.

Morris, C. R. \& Ferguson, C. H. 1993. 'How architecture wins technology wars', Harvard Business Review, 71(2):8696.

Noble, C. H., Sinha, R. K., \& Kumar, A. 2002. 'Market orientation and alternative strategic orientations: A longitudinal assessment of performance implications', Journal of Marketing, 66:25-33.

Nonaka, I. \& Takeuchi, H. 1995. The knowledge creating company. Oxford: Oxford University Press. 
Norton, D. 2002. 'Creating strategic alignment and readiness for IT’, Balanced Scorecard Report, 4(5):1-5.

Orlikowski, W. J. \& Iacono, C. S. 2001. 'Research commentary: Desperately seeking the "IT" in IT research -a call to theorizing the IT artifact', Information Systems Research, 12(2):121-131.

Osterwalder, A., Pigneur, Y. \& Tucci, C.L. 2005. 'Clarifying business models: Origins, present and future of the concept', Communications of the Association of Infromation Systems, 15: 1-40.

Palmer, J. W. 2002. 'Web site usability, design, and performance metrics', Information Systems Research, 13(2):151-167.

Polanyi, M. 1967. The tacit dimension. London: Routledge \& Kegan Paul.

Poon, S. \& Swatman, P. M. C. 1999. 'An exploratory study of small business Internet commerce issues', Information \& Management, 35:9-18.

Poon, S. 2000. 'Business environment and internet commerce benefit-a small business perspective', European Journal of Information Systems, 9:72-81.

Porter, M. E. 1980. Competitive strategy. Techniques for analysing industries and competitors. New York: Free Press.

Porter, M. E. 1985. Competitive advantage: Creating and sustaining superior performance. New York: Free Press.

Ragu-Nathan, B., Ragu-Nathan, T. S., Tub, Q. \& Shi, Z. 2001. 'Information management (IM) strategy: the construct and its measurement', Journal of Strategic Information Systems, 10:265-289.

Rappa, M. 2002. Business models on the web: Managing the digital enterprise. [online] URL:

http://digitalenterprise.org/models/models html. Accessed 7 November 2002.

Rayport, J. F. \& Jaworski, B. J. 2001. e-Commerce. New York: McGraw-Hill.

Sambamurthy, V., Bharadwaj, A. \& Grover, V. 2003. 'Shaping agility through digital options: Reconceptualising the role of information technology in contemporary firms', MIS Quarterly, 27(2):237-263.

Schumpeter, J. 1934. The theory of economic development: An inquiry into profits, capital, credit, interest, and the business cycle. Cambridge: Harvard University Press.

Schwartz, P. 2003. Inevitable surprises. Thinking ahead in a time of turbulence. New York: Gotham Books.

Simons, R. 1995. 'Control in the age of empowerment', Harvard Business Review, 73(2):80-88.
Skyrme, D. J. 2000. Knowledge networking. Creating the collaborative enterprise. Oxford: Butterworth-Heinemann.

Skyrme, D. J. 2001. Capitalising on knowledge. From ebusiness to k-business. Oxford: Butterworth-Heinemann.

Smith, M. D., Bailey, J. \& Brynjolfsson, E. 1999. Understanding digital markets: Review and assessment. [online] URL: http://ecommerce.mit.edu/papers/ude. Accessed 1 November 2002.

Snow, C. \& Hrebiniak, L. 1980. 'Strategy, distinctive competence and performance', Administrative Science Quarterly, 25:317-336.

Snow, C. M. \& Raymond, C. H. 1992. 'Managing 21st century network organisations', Organisational Dynamics, 21(5):54-62.

Straub, D. \& Klein, R. 2001. 'e-Competitive transformations’, Business Horizons, 3: 3-12.

Straub, D. 2004. Foundations of net-enhanced organisations. International edition. Hoboken: Wiley.

Sveiby, K. E. 1997. The new organisational wealth: Managing and measuring knowledge-based assets. San Francisco: Berrett-Koehler.

Sveiby, K. E. 2001. What is knowledge management. [online] URL:

www.sveiby.com/articles/KnowledgeManagement html. Accessed 28 October 2003.

Sykes, J. 1988. The concise Oxford dictionary of current English. 7 edition. Oxford: Oxford University Press.

Tapscott, D., Ticoll, D. \& Lowy, A. 2000. Digital capital. Harnessing the power of business webs. Boston: Harvard Business School Press.

Tapscott, D. 2001. 'Rethinking strategy in a networked world (or Why Michael Porter is wrong about the Internet)', Strategy + Business, 24:1-8.

Teece, D. J., Pisano, G. \& Shuen, A. 1997. 'Dynamic capabilities and strategic management', Strategic Management Journal, 18(7):509-533.

Thompson, A. A. \& Strickland, A. J. 2001. Strategic management concept and cases. 12th edition. New York: McGraw-Hill Higher Education.

Timmers, P. 2000. Electronic commerce: Strategies and models for business to business trading. March 2000 edition. Chichester, England: John Wiley and Sons.

Van de Ven, A. H. \& Drazin, R. 1985. 'The concept of fit in contingency theory'. In Cummings, L. L. \& Straw, B. M. (Eds.). Research in organizational behavior, Vol. 7. Greenwich: JAI Press, 333-365. 
Van der Zee, J. T. M. \& De Jong, B. 1999. 'Alignment is not enough: integrating business and information technology management with the balanced business scorecard', Journal ofManagement Information Systems, 16(2):137-156.

Venkatraman, N. \& Ramanujam, V. 1986. 'Measurement of business performance in strategy research: A comparison of approaches', Academy of Management Review, 11(4):801 814.

Venkatraman, N. 1989. 'Strategic orientation of business enterprises: The construct, dimensionality, and measurement', Management Science, 35(8):942-963.

Venkatraman, N. 1994. 'IT-enabled business transformation: From automation to business scope redefinition', Sloan Management Review, 35(2):73-88.

Venkatraman, N. 2000. 'Five steps to a Dot-Com strategy: How to find your footing on the Web', Sloan Management Review, 41(Spring):15-28.

Voelpel, S.C., Leibold, M. \& Streb, C.K. 2005. 'The innovation meme: Managing innovation replicators for organizational fitness', Journal of Change Management, 5(1):57-69.

Voelpel, S.C., Leibold, M. \& Tekie, E.B. 2003. The wheel of business model reinvention: How to reshape your business model and organizational fitness to leapfrog competitors. Institute of Innovation Research, Hitotsubashi University, Tokyo. Working Paper 3(10),

Voelpel, S.C., Leibold, M., Tekie, E.B. \& Von Krogh, G. 2005. 'Escaping the red queen effect in competitive strategy: Sense-testing business models', European Management Journal, 23(1):37-49.

Vorhies, D. W. \& Morgan, N. A. 2003. 'A configuration theory assessment of marketing organization fit with business strategy and its relationship with marketing performance', Journal of Marketing, 67(1):100-115.

Wang, S. 2001. 'Designing information systems for electronic commerce', Industrial Management \& Data Systems, 101(6):304-314.

Weill, P., Subramani, M. \& Broadbent, M. 2002. 'Building IT infrastructure for strategic agility’, MIT Sloan Management Review, Fall:57-65.

Weir, K. A., Kochhar, A. K., LeBeau, S. A. \& Edgeley, D. G. 2000. 'An empirical study of the alignment between manufacturing and marketing strategies', Long Range Planning, 33:831-848.

Welborn, R. \& Kasten, V. 2003. The Jericho principle. How companies use strategic collaboration to find new sources of value. New Jersey: John Wiley \& Sons.

Whittington, R. 1993. What is strategy - and does it matter. London: Routledge. 